\title{
Reducing bias in risk indices for COVID-19
}

\author{
Michał Paweł Michalak, ${ }^{1,2}$ Jack Cordes, ${ }^{3}$ Agnieszka Kulawik, ${ }^{4}$ Sławomir Sitek, ${ }^{5}$ Sławomir Pytel, ${ }^{5}$ \\ Elżbieta Zuzańska-Żyśko, ${ }^{5}$ Radosław Wieczorek ${ }^{6}$ \\ ${ }^{1}$ Institute of Earth Sciences, Faculty of Natural Sciences, University of Silesia in Katowice, Sosnowiec, \\ Poland; ${ }^{2}$ Faculty of Geology, Geophysics and Environmental Protection, AGH University of Science and \\ Technology, Cracow, Poland; ${ }^{3}$ Department of Epidemiology, Harvard T.H. Chan School of Public Health, \\ Boston, MA, USA; ${ }^{4}$ Faculty of Science and Technology, University of Silesia in Katowice, Katowice, \\ Poland; ${ }^{5}$ Department of Social and Economic Geography and Spatial Management, Faculty of Natural \\ Sciences, University of Silesia in Katowice, Sosnowiec, Poland; ${ }^{6}$ Institute of Mathematics, Faculty of \\ Science and Technology, University of Silesia in Katowice, Katowice, Poland
}

\begin{abstract}
Spatiotemporal modelling of infectious diseases such as coronavirus disease 2019 (COVID-19) involves using a variety of epidemiological metrics such as regional proportion of cases and/or regional positivity rates. Although observing changes of these indices over time is critical to estimate the regional disease burden, the dynamical properties of these measures, as well as crossrelationships, are usually not systematically given or explained. Here we provide a spatiotemporal framework composed of six
\end{abstract}

Correspondence: Michał Paweł Michalak, Faculty of Geology, Geophysics and Environmental Protection, AGH University of Science and Technology, Mickiewicza 30, 30-059 Cracow, Poland.

E-mail: michalm@agh.edu.pl

Key words: Relative risk; dynamics; COVID-19; unbiased metrics; weighting; Poland.

Acknowledgements: the article benefited from comments from four anonymous reviewers and the Editor Robert Bergquist. We thank Purvaja Kavattur for her review of the British English. The article was financially supported by the University of Silesia in Katowice (Institute of Social and Economic Geography and Spatial Management) and by the AGH University of Science and Technology (Faculty of Geology, Geophysics and Environment Protection).

Conflicts of interest: the authors declare no potential conflict of interest.

See online Appendix for additional materials.

Received for publication: 4 May 2021.

Revision received: 6 August 2021.

Accepted for publication: 7 August 2021.

CCopyright: the Author(s), 2022

Licensee PAGEPress, Italy

Geospatial Health 2022; 17(s1):1013

doi:10.4081/gh.2022.1013

This article is distributed under the terms of the Creative Commons Attribution Noncommercial License (CC BY-NC 4.0) which permits any noncommercial use, distribution, and reproduction in any medium, provided the original author(s) and source are credited. commonly used and newly constructed epidemiological metrics and conduct a case study evaluation. We introduce a refined risk estimate that is biased neither by variation in population size nor by the spatial heterogeneity of testing. In particular, the proposed methodology would be useful for unbiased identification of time periods with elevated COVID-19 risk without sensitivity to spatial heterogeneity of neither population nor testing coverage. We offer a case study in Poland that shows improvement over the bias of currently used methods. Our results also provide insights regarding regional prioritisation of testing and the consequences of potential synchronisation of epidemics between regions. The approach should apply to other infectious diseases and other geographical areas.

\section{Introduction}

Coronavirus disease 2019 (COVID-19) is caused by the novel severe acute respiratory syndrome coronavirus 2 (SARS-CoV-2) which was first discovered in late 2019 in Wuhan Hubei Province China (Huang et al., 2020). The main signs of infection include respiratory symptoms, fever, cough and breathing difficulties (WHO, 2020). Spatiotemporal analysis plays a critical role in estimating the disease burden in specific regions (Franch-Pardo et al., 2020) and has been applied in many countries, e.g., China (Huang et al., 2020; Jia et al., 2020), Spain (Briz-Redón and SerranoAroca, 2020), Italy (Bertuzzo et al., 2020; Gatto et al., 2020), Sweden (Gémes et al., 2020), Israel (Rossman et al., 2020), Brazil (Candido et al., 2020) and the United States (Miller et al., 2020; Mollalo et al., 2020). It is important to note that comparisons between regions may be challenging, which is not only because of differences in population size but also due to health policies (e.g., testing regimes) that can change over time (Mollalo et al., 2020). For example, one of the most common limitations raised when using spatiotemporal approaches relates to the lack of incorporation of spatial heterogeneity of testing (Hohl et al., 2020; Rohleder and Bozorgmehr, 2020; Zhang and Schwartz, 2020). This omission can be misleading to public health officials in terms of the public health response in regions with relatively high or low testing capabilities.

From among many measures applicable in the spatiotemporal modelling of the COVID-19 disease, the following have attracted the greatest attention: i) local (Lieberman-Cribbin et al., 2020; Gatto et al., 2020) and global (Omori et al., 2020) cumulative 
number of cases; ii) different versions of population-based relative risk (RR) - observed cases/expected cases (Desjardins et al., 2020; Rohleder and Bozorgmehr, 2020); iii) testing rates - i.e. tests/population (Lieberman-Cribbin et al., 2020); iv) local (LiebermanCribbin et al., 2020; Cordes and Castro, 2020) and global (Omori et al., 2020) positivity rates - confirmed cases/tests; and v) population-based positivity - confirmed cases/population (Cordes and Castro, 2020; Zhang and Schwartz, 2020).

Although potentially useful, the above measures were not investigated for their suitability in dynamical modelling of infectious disease. In particular, to the best of our knowledge, their dynamical properties and cross-relationships have not been systematically explained. However, knowledge of the dynamical properties of the measures used is crucial for guiding appropriate public health response. For example, health policy makers may decide that an uninterrupted increase in the cumulative version of population-based RR (Rohleder and Bozorgmehr, 2020) should necessitate the introduction of specific non-pharmaceutical interventions (NPIs) in specific regions as mentioned by Hatchett et al. (2007) in relation to the 1918-20 influenza pandemic Moreover, many of the above measures are sensitive to spatial heterogeneity of either population or testing (or both) in their identification of elevated COVID-19 burden, leading to bias. Luxembourg is a case in point: in July 2020, the country was declared a risk zone by many European countries, including Slovakia, Lithuania, Finland, Norway and Germany (RTL, 2020a). The latter country used only the cases/inhabitants metric to render Luxembourg a risk zone (RTL, 2020b). Since the measure used is biased by testing heterogeneity, countries with greater testing capabilities than others would be susceptible to being declared a risk zone. Indeed, one month later, the ban on Luxembourg was lifted by Germany and the justification was that Luxembourg had adopted a large-scale screening strategy (RTL, 2020c). However, as of the $18^{\text {th }}$ of June 2021, well-known organisations such as the German Robert Koch Institute still use 'cases per inhabitants' as the critical measure in declaring a country a risk zone. Although it is argued that testing capabilities are used in the second step of the classification, the mathematical foundations of reducing the bias due to testing heterogeneity have not been explained so far (Robert Koch Institute, 2021).

Our study offers a systematic contribution regarding a variety of spatiotemporal epidemiological measures independently used in both comparative (Cordes and Castro, 2020; Lieberman-Cribbin et al., 2020; Rohleder and Bozorgmehr, 2020) and non-comparative (Omori et al., 2020) contexts. The intention was to reveal the dynamical properties and relationships between commonly used and newly constructed epidemiological metrics with a case study application. The proposed methodology has the potential to enhance the framework of infectious disease modelling and may provide insights into how a more harmonised management of the crisis can be achieved.

\section{Case study motivation}

On the $4^{\text {th }}$ of March, 2020, the first confirmed case was registered in Poland (Raciborski et al., 2020). Four days later, more cases were identified in the densely populated Silesian region (Krzysztofik et al., 2020). As of the $17^{\text {th }}$ of August 2020, 57,286 cases had been verified in Poland, with 18,874 cases $(34.8 \%)$ attributed to the Silesian region (Ministry of Health in Poland official Twitter profile). The core of the Silesian region is referred to as the Katowice conurbation, a polycentric area consisting of 16 towns and approximately 2 million people with a population density of 1485 per $\mathrm{km}^{2}$. The largest urban centre is Katowice with 280,000 inhabitants (Runge et al., 2018). The concentration of public health efforts in Silesia follows from its large proportion of the population employed in industry $(28.7 \%)$, compared to the country mean of $20.6 \%$. Of those employed in industry in the area, $16.7 \%$ are employed in mining and exploration, which is also the largest in Poland (country mean $=4.6 \%$ ) (Statistics Poland, 2020).

After the first case in Poland was identified, NPIs were introduced, including cancelling mass events and closing borders, schools and universities among other measures (Jarynowski et al., 2020; Pinkas et al., 2020). These interventions helped flatten the curve of total number of infected individuals and delay the peak of the disease burden (as seen in Figure S1, Appendix). However, the lockdown measures applied were ultimately insufficient in terms of containing the spread of the disease in the densely populated and relatively industrially oriented Silesian region. Because it was difficult to apply WHO's social-distancing recommendations (2020) in crowded mine shafts, it was hypothesised that the spread of COVID-19 in the Silesian region was facilitated by miners who might have acted as asymptomatic carriers. The latter individuals play a vital role in the spread of the novel coronavirus (Bai et al., 2020) and undocumented infectious cases can facilitate rapid dissemination (Li et al., 2020). Indeed, according to partial results related to 50,053 screening tests within a group of mines conducted between the $7^{\text {th }}$ of May 2020 and the $25^{\text {th }}$ of June 2020 as proxy for the whole mining population, nearly $98 \%$ of the infected mine employees did not show any symptoms (Polish Press Agency, 2020a; Polska Grupa Górnicza, 2020). As of the $11^{\text {th }}$ of August 2020, 7934 miners had tested positive for COVID-19, thereby comprising nearly $44 \%$ of all infections in Silesia (Błoński, 2020a). Although the time period related to the screening tests in mines resulted in a greater population-based RR for Silesia, we still do not know: i) whether the decision on screening tests was a result of an already deteriorating epidemiological situation (with the time of the beginning of this deterioration unknown); and ii) whether in other regions with relatively low testing capabilities, the risk related to the disease existed but remained undetected.

We evaluated the proposed methodology on infection and testing rates provided by the Polish Ministry of Health: between the $4^{\text {th }}$ of March and the $17^{\text {th }}$ of August 2020 (infections) as well as between the $11^{\text {th }}$ of May and the $17^{\text {th }}$ of August 2020 (tests). The data were provided for 16 administrative regions of Poland (Figure 1) spanning an area of $312,696 \mathrm{~km}^{2}$. Because the official testing rates were published on a weekly basis, we used interpolation to estimate the testing rates for individual days. Other official reports supplemented by reports from news sources (as of the $26^{\text {th }}$ of March 2020) were also used to perform interpolation for individual days between the $26^{\text {th }}$ of March and the $11^{\text {th }}$ of May 2020. Complete details regarding interpolation are available in the Materials and Methods section.

\section{Materials and methods}

\section{Data}

We obtained daily data from the Ministry of Health in Poland on COVID-19 infections in Poland from the $4^{\text {th }}$ of March until the $17^{\text {th }}$ of August 2020. From a technical viewpoint, the data were stored in a data frame where the columns represent days and the 
rows administrative regions. A limitation of using these data was that reporting inaccuracies were not always adequately described. Although we applied 18 corrections, sometimes the calendar dates corresponding to false positive cases or detected duplicates of confirmed cases were not provided. The inaccuracies and the corresponding metadata including dates of errors and applied corrections are summarised in Table S1 (Appendix).

The data on regional testing were available for the time period between the $26^{\text {th }}$ of March and the $17^{\text {th }}$ of August 2020. The reports from the $11^{\text {th }}$ of May 2020 onward were provided by the Ministry of Health in Poland on a weekly basis in the form of the cumulative number of tests conducted for every region. However, it should be noted that these cumulative data did not include the full day of publishing but were restricted to a specific hour of the day. For example, cumulative regional data on testing published on the $17^{\text {th }}$ of August 2020 covered the time period between the $4^{\text {th }}$ of March and the $17^{\text {th }}$ of August as given at 1:00 P.M.

We also used official fragmentary reports as well as an unofficial incomplete report for the $26^{\text {th }}$ of March 2020 from a news source as described in Table S2 (Appendix). Data on regional testing were not publicly available for days preceding the $26^{\text {th }}$ of March 2020, so we excluded this period from the analysis. There was concern about the limited reliability of test data for the Kielce region for which about 241,000 tests were erroneously registered (Ministry of Health in Poland, 2020). Although the correction was applied on the $8^{\text {th }}$ of August 2020 (Ministry of Health in Poland, 2020), the historical data were not officially corrected. We there- fore subtracted the superfluous number of tests evenly throughout the time period for this region. Population census data were obtained from the official repository Demographic Yearbook of Poland (Statistics Poland, 2020).

\section{Simultaneous standardisation with respect to popula- tion and testing}

The RR notion is often used to investigate the spatial distribution of cases (Waller and Gotway, 2004; Bivand et al., 2013; Desjardins et al., 2020) and this metric is inherently related to the concept of indirect standardisation (Waller and Gotway, 2004). It involves calculating the standardised incidence ratio (SIR) which accounts for the differences in population size among regions. Typically, the SIR value depends on the individual daily infection rate and is calculated as the ratio between the observed number of cases (infections) in a region and the expected number based on the regional population. Values greater than 1 suggest an elevated risk compared to the population average, which may indicate infection clusters or a greater number of vulnerable groups (Desjardins et al., 2020). To alleviate the impact of daily fluctuations and create a framework for comparing the present state with historical reference, a cumulative estimate can be applied (Rohleder and Bozorgmehr, 2020), which we refer to as the cumulative standardised incidence ratio (CSIR). It is calculated for a specific day $t$ as the ratio of the confirmed number of cases since the outbreak of the pandemic including day $t$ to the expected cumulative number of

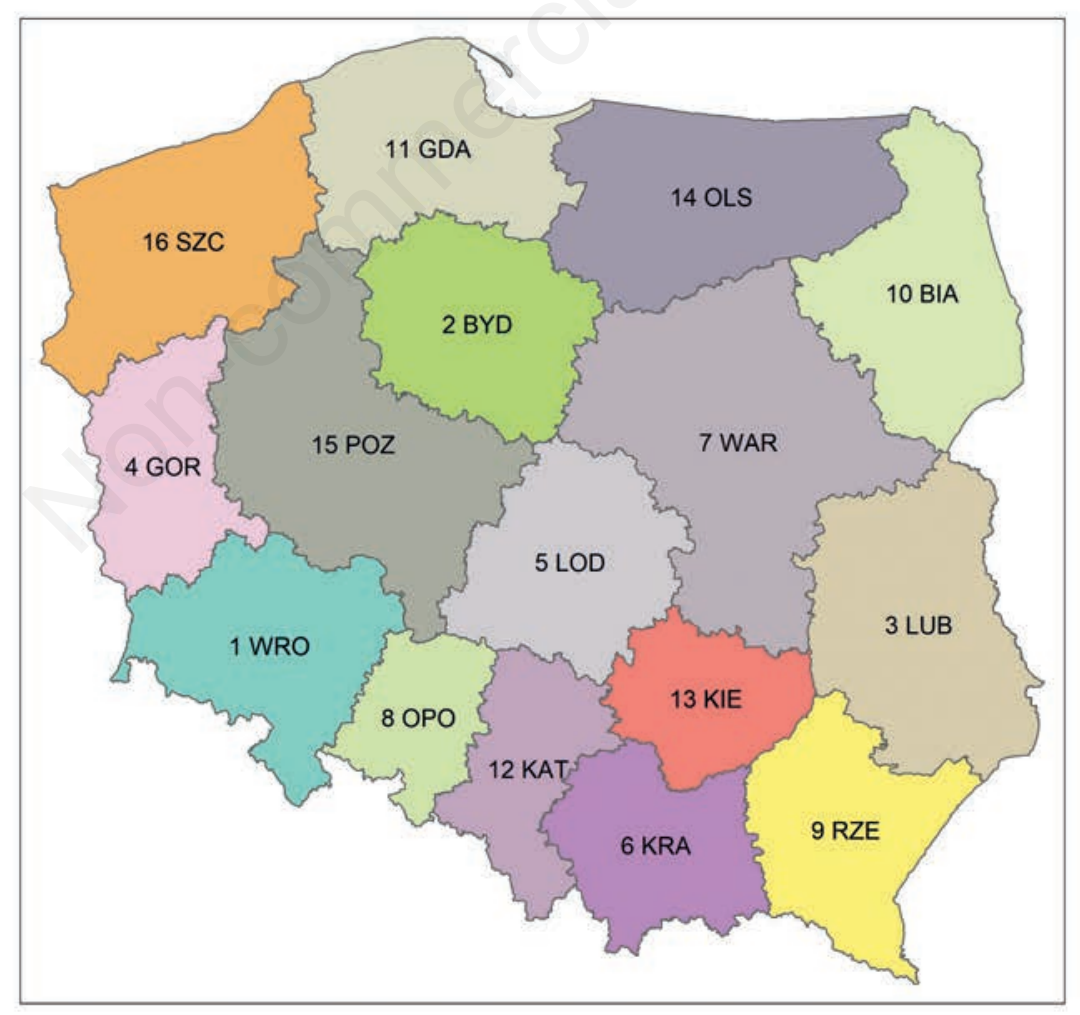

Figure 1. Map of Poland and its administrative regions. Full names and capitals (in parentheses): 1 WRO - Dolnoslaskie (Wrocław), 2 BYD - Kujawsko-pomorskie (Bydgoszcz), 3 LUB - Lubelskie (Lublin), 4 GOR - Lubuskie (Gorzow Wielkopolski), 5 LOD - Lodzkie (Lodz), 6 KRA - Malopolskie (Krakow), 7 WAR - Mazowieckie (Warszawa), 8 OPO - Opolskie (Opole), 9 RZE - Podkarpackie (Rzeszow), 10 BIA - Podlaskie (Bialystok), 11 GDA - Pomorskie (Gdansk), 12 KAT - Slaskie (Katowice), 13 KIE - Swietokrzyskie (Kielce), 14 OLS - Warminsko-mazurskie (Olsztyn), 15 POZ - Wielkopolskie (Poznan), 16 SZC - Zachodniopomorskie (Szczecin). 
cases on day $t$. From a dynamical viewpoint, this ratio is equivalent to the regional cumulative proportion of cases for a specific day $t$ and region. It may decrease or increase depending on whether the proportion of cases for $i$ on day $t$ is lower or greater than the cumulative proportion for $i$ on the preceding day $(t-1)$. The limitation of comparing regions using this risk estimate is that it stays unbiased as long as there is spatial homogeneity regarding testing intensity. To overcome potential bias, we first applied an analogous procedure for the data related to regional testing, which means that we calculated a quantity referred to as the cumulative standardised testability ratio (CSTR), i.e. the proportion of the number of observed tests in relation to that of the expected tests in a given region. It is important to understand that this value can be interpreted as an estimate of the relative safety because the greater the quantity the more efficiently NPIs can be applied. We then divided the CSIR by the CSTR to get a refined estimate of the RR, which we call the weighted cumulative standardised incidence ratio (WCSIR). It follows that the WCSIR remains unchanged from the CSIR only if the CSTR $=1$, which means that the number of tests is equal to the expected number of tests. Otherwise, the RR increases or decreases depending on whether the CSTR is smaller than or greater than 1, respectively. The WCSIR risk estimate is therefore neither biased by differences in population size nor by differences in the amount of testing in a specific region. In other words, the WCSIR measure allows testing intensity to be heterogeneous and it captures the change in RR by honouring the following expectations for a specific region: i) the risk measure should decrease/increase if the regional infection ratio (regional infected/global infected) decreases/increases and the analogous test rate (regional tests/global tests) increases/decreases; and ii) the risk measure should decrease/increase if the cumulative global positivity rate (GPR) (cumulative confirmed cases/cumulative tests) increases/decreases, while the analogous local positivity rate (LPR) decreases/increases.

Alternatively, but equivalently (Eq. 4 in Materials and methods section), the WCSIR could be conceptualised as the ratio of LPR to GPR for a given region. Therefore, WCSIR equals 1 only if $\mathrm{LPR}=\mathrm{GPR}$, otherwise the RR increases or decreases depending on whether the LPR is greater than or less than GPR, respectively. In the second conceptualisation (WCSIR=LPR/GPR), the GPR acts as a useful normalisation constant common for all regions, which assists the separation of more risky regions in terms of the positivity rate (WCSIR $>1$ ) from less risky ones (WCSIR $<1$ ). As such, we anticipated our study to be a starting point for considering more sophisticated RR estimates. For example, even if the dynamics of the regional proportion of cases show a positive trend for a given region, our methodology can classify this region as one with decreasing risk if the local and global positivity rates move in opposite directions, i.e. decrease and increase, respectively. The flexibility of this second conceptualisation of WCSIR also affords opportunities to overcome potential difficulties in obtaining population data, which may be the case when a testing site cannot easily be split into regions with known population information. Given these two conceptualisations, the resulting value of WCSIR has two interpretations: a WCSIR of 2 must be interpreted simultaneously as: i) the CSIR is twice the CSTR; and ii) the LPR is twice the GPR.

\section{Estimation of relative risk}

To estimate the relative risk (RR) in regions of interest we used the concept of indirect standardisation (Waller and Gotway, 2004; Bivand et al., 2013). The general formula for estimating the RR can be written as follows: $O / E$, where $O$ and $E$ denote the observed and the expected number of cases respectively. Given a specific region $i$ to obtain $E_{i}$, it is first necessary to calculate a global rate $r$ $=\sum_{i} O_{i} / \sum_{i} P_{i}$, where $\sum_{i} P_{i}$ denotes the total population. It is then straightforward to calculate $E_{i}$ as $P_{i} r$, with $P_{i}$ being the population in region $i$. For example, if the proportion of cases in Poland is $2 \%$, then the expected number of cases in Silesia would be $2 \%$ of its population, which assumes a spatially homogenous distribution of cases (Bivand et al., 2013). We must now differentiate between two versions of calculating the RRs in our study: i) standardisation based on population: SIR and CSIR; and ii) weighting relative infection ratios by relative testing ratios: WCSIR based on CSIR and CSTR.

For the SIR, the totals of the observed number of cases and the expected number of cases $E_{i}$ refer to the daily number of cases. If we denote $x_{i, t}$ as the observed number of cases on day $t$, and $E_{i, t}$ as the expected number of cases on day $t$, we arrive at the following formula:

$$
\operatorname{SIR}_{i}(t)=\frac{x_{i, t}}{E_{i, t}}=\frac{x_{i, t}}{P_{i} r_{t}}=\frac{x_{i, t}}{P_{i} \frac{\sum_{i} x_{i, t}}{\sum_{i} P_{i}}}
$$

For the CSIR, we assume that for a specific day $t$, the observed number of cases in region $i$ is the sum of the observed number of cases in $i$ for days $j \in[1, t]$. Similarly, to calculate the corresponding global rate we assume that the observed number of cases is the sum of all cases that were confirmed in Poland for days $j \in[1, t]$. Then, the expected number of cases is the global rate multiplied by the population size in $i$. The CSIR is then calculated as the proportion between the observed and expected number of cases. If we denote $O_{i, t-1}=\sum_{j=1}^{t-1} x_{i, j}$ as the cumulative number of cases for region $i$ up to day $t-1$, and $E_{i, 1: t}$ as the expected cumulative number of cases for $i$ on day $t$, then the formula for CSIR becomes:

$\operatorname{CSIR}_{i}(t)=\frac{o_{i, t-1}+x_{i, t}}{E_{i, 1: t}}=\frac{o_{i, t-1}+x_{i, t}}{P_{i} \frac{\sum_{i}\left(o_{i, t-1}+x_{i, t}\right)}{\sum_{i} P_{i}}}$

It follows that the current value of CSIR is to a large extent governed by the past (cumulative cases from days 1 up to $t-1$ ) and the contribution of the present day $t$ weakens with time. This explains why the curves are smooth: the present has a smaller effect than the past. To sum up, the past contributes primarily to the present state and its role in shaping the present increases with time.

Similarly, the information on the number of tests conducted for each region can be employed to estimate the relative safety, not to be confused with the safety perspective presented in Figure S10 (Appendix). The corresponding CSTR was calculated in an analogous procedure to that of the CSIR. If we denote $T_{i, t-1}$ as the cumulative number of tests conducted for region $i$ up to day $t-1 ; y_{i, t}$ as the number of tests conducted for $i$ on day $t$; and $T E_{i, 1: t}$ as the cumulative expected number of tests for $i$ on day $t$; then the formula for CSTR becomes:

$$
\operatorname{CSTR}_{i}(t)=\frac{T_{i, t-1}+y_{i, t}}{T E_{i, 1: t}}=\frac{T_{i, t-1}+y_{i, t}}{P_{i} \frac{\sum_{i}\left(T_{i, t-1}+y_{i, t}\right)}{\sum_{i} P_{i}}}
$$


The interpolation procedure was conducted as follows. We first used the 'interpolate_tests' function to estimate the cumulative number of tests for individual days assuming a constant intercept. For example, if the cumulative number of tests for region $i$ were 1000 and 8000 on the $11^{\text {th }}$ of May and the $18^{\text {th }}$ of May, respectively, then the intercept for every day related to this time window would

be equal to $\frac{8000-1000}{7}=\frac{7000}{7}=1000$. Then, to obtain the approximate value of CSTRs for individual days, the 'relrisk' function in R was used. We note that the assumption of a constant intercept may not be realistic, but we are not ready to commit to the idea of the best interpolation method in case of differences in temporal resolution between data on infections and testing. To avoid edge-effects that are inherent for the interpolation method, statistical approaches including best-fitting curves could be employed. However, the main disadvantage of this statistical procedure is that one cannot expect that the official data of the cumulative number of tests will be honoured at nodes. The interpolation enabled the weighted estimates to be obtained through the division of data on infections and testing. The corresponding equations of the resulting WCSIR are as follows (observed cases/expected cases) / (observed tests/expected tests):

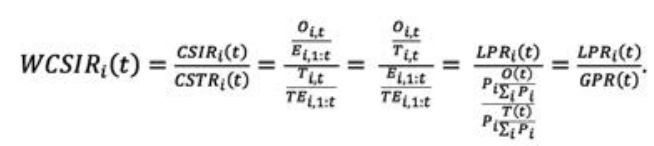

We used a global Moran's $I$ coefficient, using queen adjacency as the neighbourhood definition, to investigate the presence of spatial autocorrelation (clustering) throughout the time period (Moran, 1950). Moran's $I$ is a measure that evaluates the covariance of a value $\mathrm{X}$ at an index location $i$ with the average of the values $\mathrm{X}$ of its neighbours $j$. Moran's $I$ values range from -1 , indicating dissimilar values cluster together, to +1 , indicating similar values cluster together. A value of 0 indicates complete spatial randomness.

From a methodological viewpoint, we note that the curves presented here could also be viewed as a measure of relative safety in the form of $1 / \mathrm{RR}$. This safety perspective provides a better visualisation of regions with the lowest RR values, which the CSIR or WCSIR estimates struggle to distinguish (Figure S10).

\section{Local and global positivity rates}

Because the relationship between local and global dynamics of the cumulative proportion of positive cases exerts influence on the dynamics of WCSIR, we provide formulas for these measures as follows:

$$
\begin{gathered}
\operatorname{LPR}_{i}(t)=\frac{o_{i, t}}{T_{i, t}} \\
\operatorname{GPR}(t)=\frac{o(t)}{T(t)}
\end{gathered}
$$

The computational objectives corresponding to functions included in the computer code are summarised in Table 1 (see also Code availability section for a link to the 'shinyApp'). We used the following R packages: dplyr (Wickham et al., 2019), ggplot2 (Wickham, 2016), ggpubr (Kassambara, 2020), reshape2 (Wickham, 2007), tibble (Müller and Wickham, 2020), sf (Pebesma, 2018), tmap (Tennekes, 2018), broom (David and Hayes, 2019), plotly (Sievert, 2018) and magrittr (Milton Bache and Wickham, 2014).

\section{Results}

\section{Unweighted risk}

The SIR analysis revealed that the RR values in the Silesian region were largely greater than one since mid-April 2020, and on five days in late April and early May (Figure 2A) this value was greater than 3, all before the decision was taken to screen for COVID-19 in mines. In the 28 days after implementation of this testing policy, SIR values were always greater than 3 , with a maximum value 6.92 on the $12^{\text {th }}$ of May 2020, with fluctuations between 4 and 6 . However, the greater than expected number of cases since mid-April suggests that the outbreak might have originated earlier than the decision to test the miners. Indeed, CSIR curves showed a rising trend prior to the decision to implement the screening in Silesia, largely after the Easter holiday (9-13 April 2020) (Figure 2B). The close to monotonously rising CSIR trajectory between mid-April and mid-June 2020 denotes the progressive relative deterioration of the epidemiological situation in Silesia in this time period.

Table 1. Description of functions included in the computer code ( $R$ script).

\begin{tabular}{ll} 
Function & What does it do? \\
cumulate_df & Cumulates a data frame \\
relrisk & Calculates SIR. Can also provide input to interpolate_tests function \\
\hline relrisk_cum & Calculates CSIR \\
sum_cum & Calculates cumulative sum of observed cases for every day \\
\hline interpolate_tests & Calculates CSTR \\
weighted_risk & Calculates WCSIR \\
\hline reorder & Assigns risk CSIR and WCSIR values to polygons in shapefiles \\
\hline
\end{tabular}

Code, data and the 'shinyApp' can be accessed via links given in the Code availability section. SIR, standardised incidence ratio; CSIR, cumulative SIR; WCSIR, weighted cumulative SIR. 


\section{Weighted risk}

As discussed above, the RR estimates presented in Figure 2 were biased by regional differences in testing intensity. Figure S2 (Appendix) shows that the highest testing intensity was observed for the Warszawa region throughout the epidemic, with the lowest positions occupied by the Opole and Rzeszów regions. According to the WCSIR estimate (Figure 3; lowest part of Figure 4) the Opole region was the area of least safety during the height of the epidemic in Poland (between the $11^{\text {th }}$ of April and the $18^{\text {th }}$ of May 2020) occupying the second position at the end of the study period, with a substantial distance to the third-ranked Rzeszów region. Although a positive difference between CSIR and WCSIR for both Silesia and Opole can be observed in Figures 3 and 4, this difference was smaller for Silesia with the corresponding curves more or less parallel (Figure 3). The Opole region did not show this parallelism, but there was instead a stronger difference between the CSIR and WCSIR curves with a diverging pattern in mid-May: the WCSIR increased in the 13-18 May period, with a simultaneous decrease in CSTR; an increase in CSIR was also observed, but only in the 15-17 May period. This means that the weighted risk estimate may increase even if the unweighted risk decreases.
A

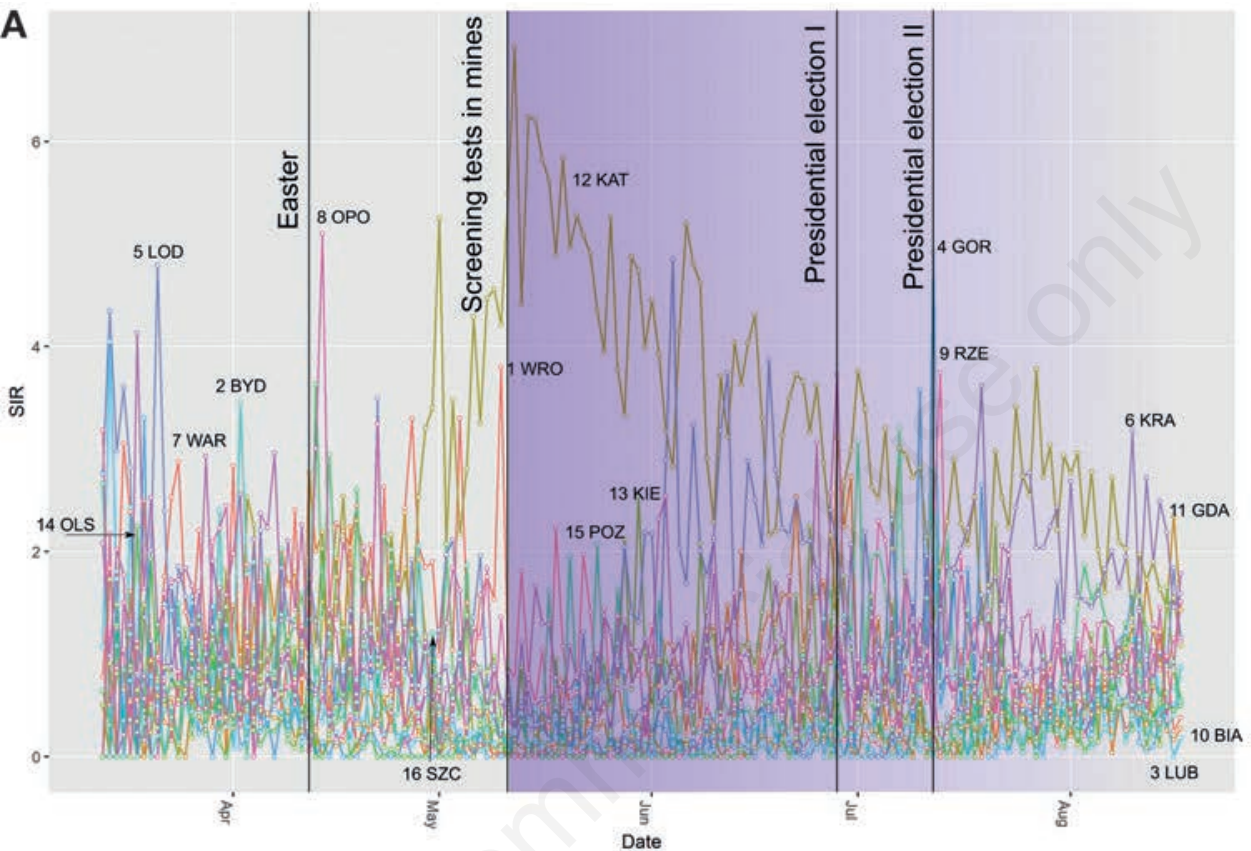

B

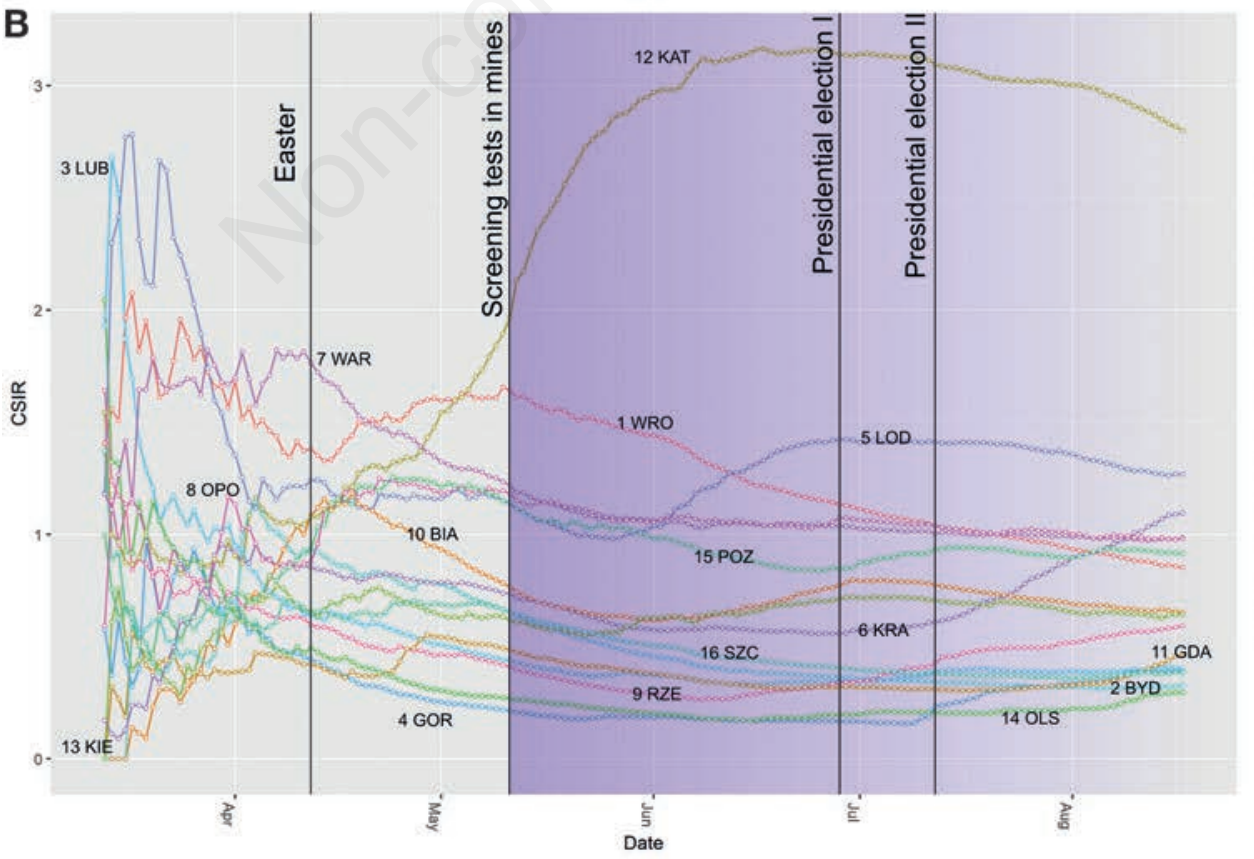

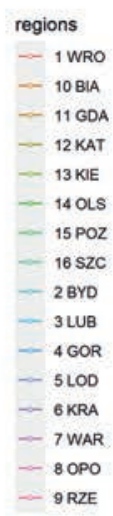

regions

- 1 WRO

- 10 BIA

- $11 \mathrm{GDA}$

- 12 KAT

- $13 \mathrm{KIE}$

- 14 OLs

- $15 \mathrm{POZ}$

$16 \mathrm{SzC}$
-

- 2 BYD

- 3 LUB

$\angle 4$ GOR

- 5 LOD

$-6 \mathrm{KRA}$

- TWAR

- 8 OPO

- 9 RZE

Figure 2. Daily time series of the (A) standardised incidence ratio (SIR) and the (B) cumulative standardised incidence ratio (CSIR) by region in Poland; the gradient denotes the assumed decreasing intensity of screening tests with time. 


\section{Dynamic and spatial patterns}

A more comprehensive analysis of the relationships between the cumulative measures CSTR, CSIR, WCSIR and the LPR-GPR tandem (Figure S3 - Appendix) can be conducted by plotting daily values of two selected measures on a Cartesian plane (Figures 5 and S4-S9 - Appendix). Summing up the results from all 16 regions, we highlighted six potentially distinct, emerging trajectories. Figure 5A shows the ideal situation when CSIR and WCSIR decrease together throughout the period, as exemplified in the Wrocław region. This pattern reflects that although the CSTR may be increasing at times, the CSIR is decreasing (Figure S4A Appendix). This suggests that the disease burden in this region should be very low. The Warszawa region shows the second pattern with a decreasing value of CSIR associated with increasing WCSIR and LPR values (Figure 5B and S5B - Appendix). Interestingly, Figure S5B illustrates that the dynamics of LPR and WCSIR are not equivalent. For example, the LPR remained constant, while the WCSIR climbed almost vertically in July 2020. This suggests that the normalisation of LPR by GPR may be helpful for detecting increasing disease burden earlier. The trajectory of the Opole region represents the third pattern: while the CSIR was approximately constant, the WCSIR rose fast (Figure 5C) confirming the divergent pattern in mid-May 2020, observed in Figure 3. We note, however, that the LPR and WCSIR showed a decreasing trend since June 2020 in this region (Figures 5C and S5C Appendix). Interestingly, the change of trajectory from decreasing to increasing in the Opole region for the CSTR resulted in a simultaneous rapid decrease of WCSIR and a steeper decrease of LPR. This suggests that the high probability of finding infected individuals was due to insufficient testing intensity. Figure 5D shows the fourth pattern with an undesirable change of the trajectory of the relationship, as typified by the Rzeszów region since mid-June 2020. The acute angle, corresponding to the rapid change of LPR dynamics (Figure S6D - Appendix), suggests that it might have been caused by a particular outbreak. For Silesia (Figure 5E) we observed the fifth pattern, i.e. a plateau after initial growth of both CSIR and WCSIR. This may be due to a largely decreasing LPR since June 2020, when it reached a maximum of $10.25 \%$ (Figure S3). The fact that it took only two weeks after the adoption of screening tests in mines to revert the WCSIR dynamics to their values early in the epidemic suggests that the strategy was successful. The final pattern, exemplified by the Poznań region (Figures 5F and S7-S8F- Appendix), was the change in direction of the CSTR trajectory that started to decrease in mid-June 2020. Although the LPR was still decreasing within one month from the change, it subsequently started to increase (Figure S9F - Appendix) with undulating CSIR and WCSIR values (Figures 5F and S4F - Appendix). In this pattern, it is interesting to note that the WCSIR dynamics also reverted to higher levels within two weeks of the change in the CSTR dynamics, which suggests that reduced testing intensity may ultimately result in a greater relative disease burden.

The global Moran's $I$ for the WCSIR estimate showed an increasing trend since early April after initial random variations at

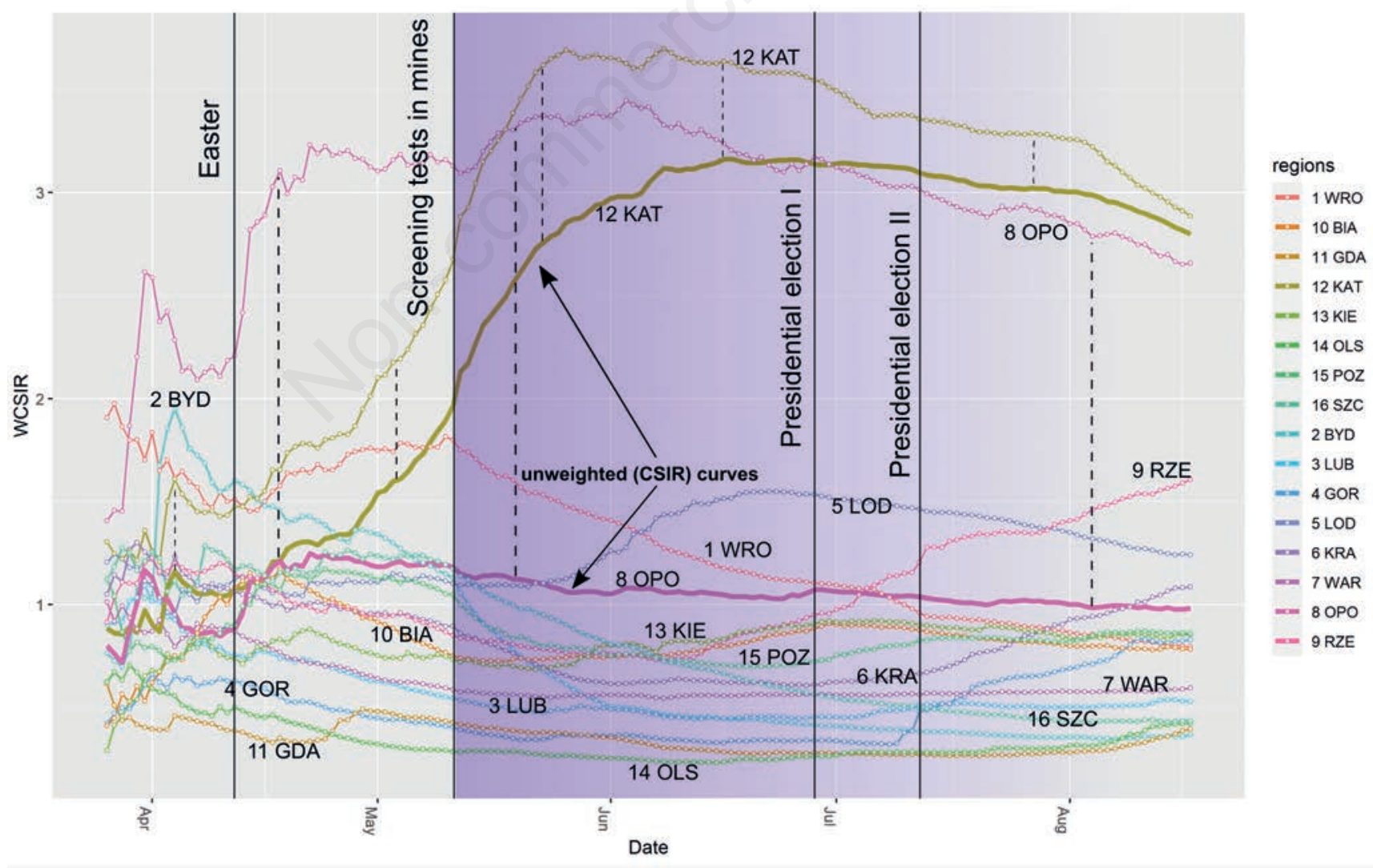

Figure 3. The weighted cumulative standardised incidence ratio (WCSIR) by region in Poland. Two unweighted CSIR curves (bolded) illustrate the impact of weighting. The gradient denotes the assumed decreasing intensity of screening tests with time. 
the beginning of the time period (Figure S11 - Appendix). It reached a plateau at 0.30 in mid-June 2020. We hypothesise that the monotonous rise may be due to a progressive synchronisation of epidemics between neighbouring regions. This synchronisation can be exemplified by similar values of WCSIR between Opole ( 8 OPO) and Silesia (12 KAT) regions (Figure 4). We note that the Moran's I can also be calculated for the biased version of RR, and it shows smaller values with a different dynamics, which would be potentially misleading about the epidemiological synchronisation underlying the spatial autocorrelation patterns (Figure S11 Appendix).

\section{Discussion}

The weighted approach applied in this study is particularly useful when spatial homogeneity in testing intensity cannot be assumed, which was the case in our example. For instance, as of the $17^{\text {th }}$ of August 2020, the Warszawa region was tested nearly 4.5 times more intensely $(\mathrm{CSTR}=1.66)$ than the Rzeszów region $(\mathrm{CSTR}=0.37)$. Given these disproportions, inferring the epidemic dynamics from the confirmed number of cases or metrics such as 'cases per 100,000 inhabitants' cannot be justified (TVN24, 2020). We also showed the official statements to be false with regard to the Silesia as the most tested region (CSTR never $>1$ as of the $17^{\text {th }}$ of August 2020 (Polish Press Agency, 2020b), the epidemiologically safest region (Polsat, 2020), or epidemiologically unexceptional (both CSIR and WCSIR >1) (RMF24, 2020).

The refined results could be utilised by authorities and health crisis managers to introduce more integrated NPI policies for adjacent regions that might be epidemiologically synchronised (Balcan et al., 2009; Dalziel et al., 2018). In our case, the similarity between WCSIR values and the relatively high positivity rates throughout the study period suggest that synchronisation could be the case for the Opole and Silesia regions. In the summer of 2020, differences in organising public gatherings remained in these regions. For example, church authorities allowed the organisation of city-wide processions at the Feast of Corpus Christi (on the $11^{\text {th }}$ of June, 2020) in the Opole region (Ogiolda, 2020), whereas in Silesia mass gatherings of this kind were forbidden (ChruścińskaDragan, 2020). Because public gatherings played a vital role in the spread of the 1918-1920 influenza pandemic (Cobey, 2020; Hatchett et al., 2007), it is necessary to stress the significance of the joint effect of testing and infection indices to prevent downplaying the epidemiological risk in poorly tested and/or less populated regions. Using a cumulative RR estimate, we demonstrate that systematic growth in infections already started in mid-April, three weeks before the decision to implement screening tests in the

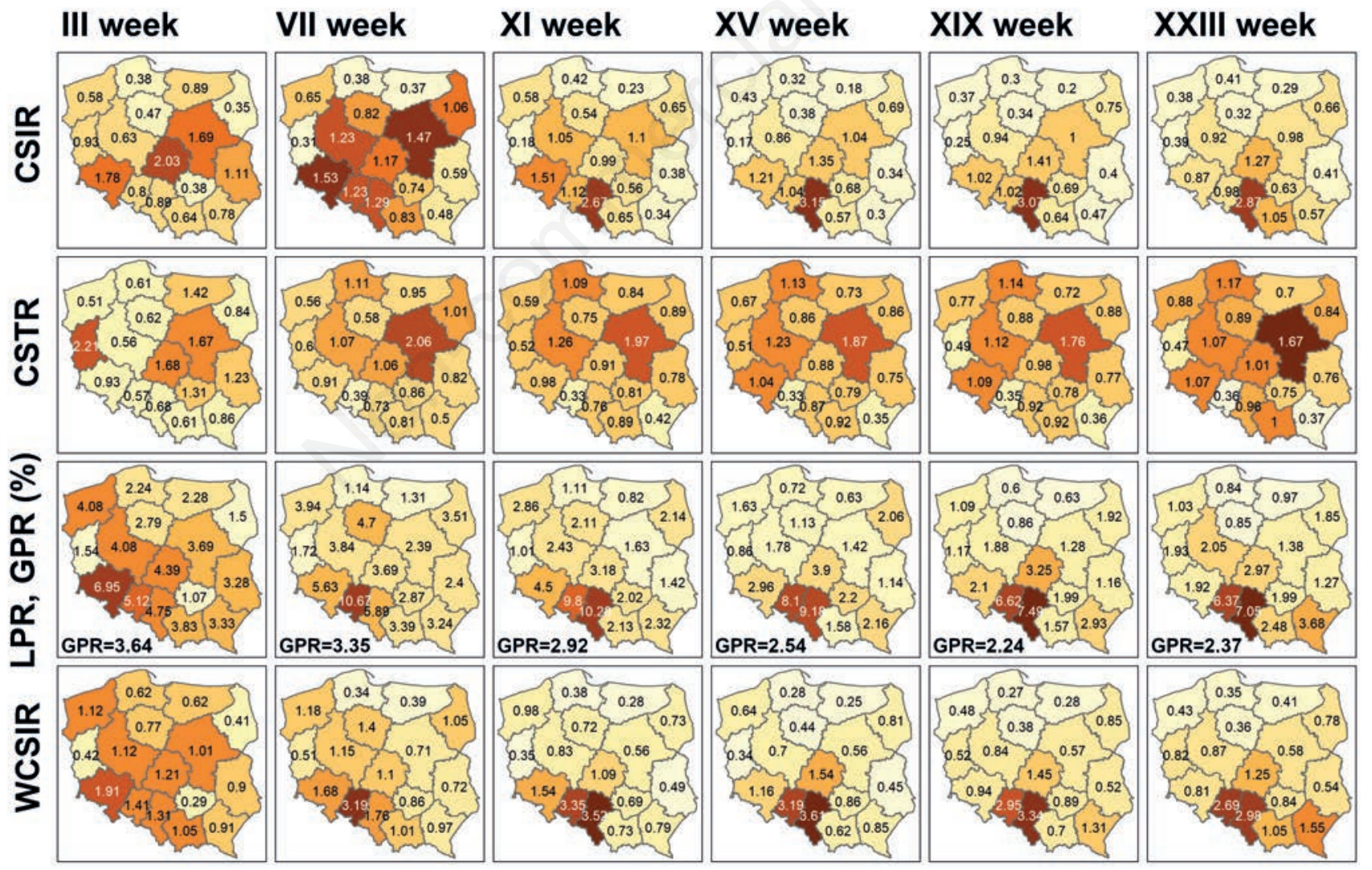

Figure 4. COVID-19 epidemiological measures for the administrative regions in Poland. CSIR, cumulative standardised incidence ratio; CSTR, cumulative standardised testability ratio; LPR, local positivity rate; GPR, global positivity rate; WCSIR, weighted cumulative standardised incidence ratio illustrate the impact of weighting. The gradient denotes the assumed decreasing intensity of screening tests with time. 
Silesian mines. This early peak is concerning as the lack of screening tests at the time of the potentially greater, though unknown, mobility corresponding to Easter may have facilitated the local spread of the disease among the mostly asymptomatic and thus undetected carriers. We note however that the epidemiological deterioration did not affect all mines equally and it was highly variable throughout the study period: while at the end of June, 2020, the positivity rate calculated for a group of several mines did not exceed 4\% (1862 confirmed cases/50,053 tests) (Polska Grupa Górnicza, 2020), one month later a screening test conducted for one mine from this group revealed about $35 \%$ population-based positivity (156 confirmed cases/452 employees) (Błoński, 2020b). Surprisingly, the systematic deterioration and highest positivity rate in May for Silesia coincided with a temporal concentrated increase in one particular mine in which the population-based positivity climbed from about $5 \%$ (as of the $14^{\text {th }}$ of May 2020) to $28 \%$ (as of the $24^{\text {th }}$ of May 2020) and to $33 \%$ (as of the $29^{\text {th }}$ of July 2020).

Investigation of the spread of COVID-19 in similar conditions has previously been carried out in the densely populated region of Buenos Aires, Argentina with 13 million inhabitants in 41 districts (Tagliazucchi et al., 2020). This research revealed that the spread of the disease radiated from the central city through suburban districts to neighbouring regions. There are however two major differences underlying the spread of the disease in Buenos Aires versus the Silesian region. While the first difference is related to the very specific spatial structure of the Silesian region, the second points at the greater role of industry rather than population density in the spread of the disease. Other studies have likewise shown that population density (Ramírez-Aldana et al., 2020; Zhang and Schwartz, 2020), age structure (Zhang and Schwartz, 2020) and socioeconomic status (Cordes and Castro, 2020; Mollalo et al., 2020; Ramírez and Lee, 2020) among other variables affect COVID-19 transmission patterns strongly, while our study adds information regarding how an area's relative dominance in an economic sector can play a role in the transmission. However, we underline that the mining industry should only be regarded as a proxy of the infectious potential of large industrial plants. Indeed, similar events were registered in other regions (e.g., in the Poznan region in a meat-processing company in early August, 2020 (313 confirmed cases/800 employees) (Orlikowski, 2020). Given that large companies may attract employees from more distant localities, they have the potential to synchronise the epidemics at the sub-regional level, given that individuals may acquire the infection at work but still be
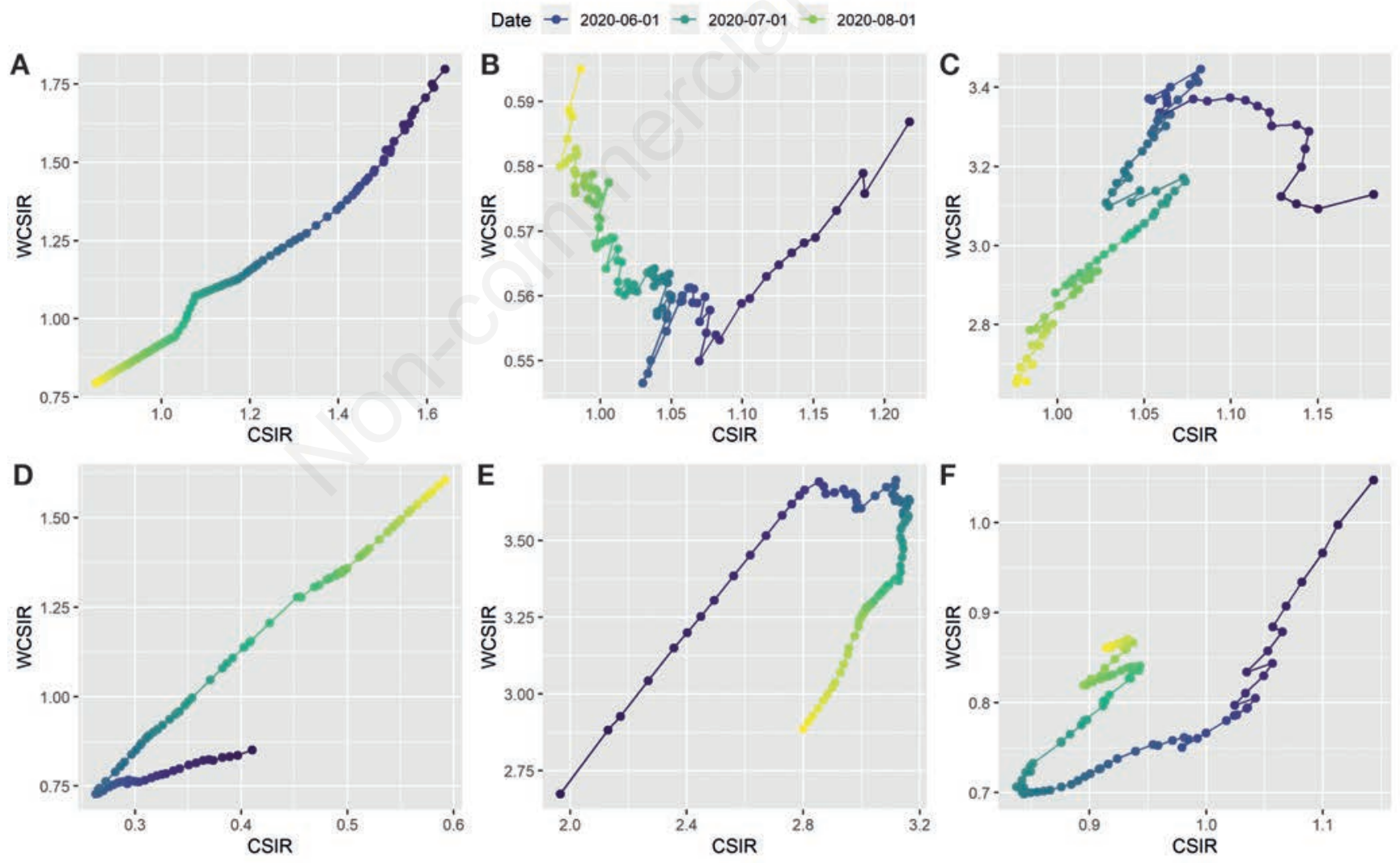

Figure 5. Relationship between the cumulative standardised incidence ratio (CSIR) and the weighted cumulative standardised incidence ratio (WCSIR) curves for individual regions. A) Wroclaw region - both CSIR and WCSIR values are decreasing; B) Warszawa Region CSIR is decreasing and WCSIR is increasing; C) Opole Region - divergent pattern of CSIR and WCSIR; D) Rzeszów Region both CSIR and WCSIR are increasing; E) Katowice (Silesia) Region - initial proportional growth of CSIR and WCSIR followed by plateau; F) Poznań Region a change in trajectory followed by a zigzag pattern between CSIR and WCSIR. 
counted in their home region (Balcan et al., 2009). For example, if a company is located in region A but close to the boundary with region $\mathrm{B}$, then two persons working in this company but living in sub-regions $\mathrm{a}$ and $\mathrm{b}$ ( $\mathrm{a}$ in $\mathrm{A}$ and $\mathrm{b}$ in $\mathrm{B}$ ) may lead to synchronisation of epidemics between $\mathrm{a}$ and $\mathrm{b}$ (thus $\mathrm{A}$ and $\mathrm{B}$ ). Therefore, particular attention should be paid to the fact that synchronisation may occur in administrative regions with different testing capabilities. Also, because testing capabilities have so far been limited, the results obtained after weighting could be used to consider regional prioritisation in the availability of tests. For example, from Table 2 it could be inferred that the following regions are in particular need for increased testing intensity: Opole (8 OPO: $+170.53 \%$ ) and Rzeszów (9 RZE: $+171.41 \%$ ). Therefore, we support calls for a radical increase in the identification of positive cases and accompanying isolation, and we encourage increased awareness and behavioural changes of COVID-19 to help reduce its spread (Bergquist and Rinaldi, 2020; Chinazzi et al., 2020; Li et al., 2020).

\section{Limitations}

The main limitation of this study follows from the incompleteness of official data related to testing that are publicly available only since the $11^{\text {th }}$ of May 2020 (details in Materials and methods section). For the time period between the $26^{\text {th }}$ of March and the $11^{\text {th }}$ of May, the results of weighting approaches and positivity rates are estimated with greater uncertainty, and we urge more caution in interpreting estimates at the beginning of the time period. The confirmed, yet unexplained, underreporting for Silesia resulting in an approximate $8 \%$ underestimate of cases (as of the $9^{\text {th }}$ of July, 2020) as well as the limited reliability of test data for Kielce region (Medonet, 2020), pose additional interpretation difficulties (Watoła, 2020). An additional limitation is that there may be other unknown differences in test regimes influencing the results. For example, poorly investigated regions may decide that only very suspicious cases will be tested, which would result in relatively high positivity rates (Omori et al., 2020). We also did not include information on recovered individuals, i.e. those with two consecutive negative tests (Niżankowski et al., 2020), which underestimates the positivity rates for the time period in which the number of recovered patients increases. It should also be stressed that the theorem regarding the dynamics of WCSIR implies that a causal relationship between a decrease of WCSIR and either of the alternatives cannot be established. Another issue is that for every cumulative measure (CSTR, CSIR, LPR, GPR, and WCSIR), the accumulation interval for day $t$ is from day 1 to day $t$. One disadvantage in using such an accumulation interval is that the role of the past in shaping the present increases with time (see Materials and meth$o d s$ section for explanation). Thus, the curves do not necessarily reflect the current epidemiological situation. However, the main advantage is that it allows for evaluation of whether the present epidemiological state is better or worse compared to the whole past situation (see Theorem 1 with an example for CSIR in Appendix).

\section{Conclusions}

This study proposed a new risk index for assessing COVID-19 burden. Since many biased measures are still used to assess the COVID-19 risk (e.g., Robert Koch Institute, 2021), public health guidance is susceptible to erosion of trustworthiness when risk recommendations revert based on inadequate measures (e.g., as described for Luxembourg). We explain the mathematical foundations of reducing the bias by combining four risk metrics into one. The theoretical and empirical considerations resulted in the following conclusions:

i) The proposed risk measure (WCSIR) is relative in nature, and it can be conceptualised either as weighting relative infection risk by relative intensity of testing or as normalising local pos-

Table 2. Estimates of the relative risk as of the $17^{\text {th }}$ of August 2020, using unweighted and weighted approaches, relative change and corresponding positions.

\begin{tabular}{|c|c|c|c|c|c|}
\hline Region & CSIR & Rank 1 & Relative change (\%) & WCSIR & Rank 2 \\
\hline $1 \mathrm{WRO}$ & 0.85 & 7 & -6.70 & 0.79 & 9 \\
\hline $2 \mathrm{BYD}$ & 0.33 & 15 & +11.60 & 0.37 & 16 \\
\hline 3 LUB & 0.40 & 12 & +31.76 & 0.53 & 12 \\
\hline $4 \mathrm{GOR}$ & 0.39 & 13 & +112.31 & 0.83 & 8 \\
\hline $5 \mathrm{LOD}$ & 1.27 & 2 & -2.03 & 1.24 & 4 \\
\hline $6 \mathrm{KRA}$ & 1.09 & 3 & -0.73 & 1.09 & 5 \\
\hline 7 WAR & 0.99 & 4 & -39.66 & 0.60 & 11 \\
\hline $8 \mathrm{OPO}$ & 0.98 & 5 & +170.53 & 2.66 & 2 \\
\hline 9 RZE & 0.59 & 10 & +171.41 & 1.61 & 3 \\
\hline $10 \mathrm{BIA}$ & 0.65 & 8 & +19.97 & 0.78 & 10 \\
\hline $11 \mathrm{GDA}$ & 0.47 & 11 & -15.24 & 0.40 & 15 \\
\hline $12 \mathrm{KAT}$ & 2.80 & 1 & +3.10 & 2.89 & 1 \\
\hline $13 \mathrm{KIE}$ & 0.64 & 9 & +33.05 & 0.85 & 7 \\
\hline $14 \mathrm{OLS}$ & 0.30 & 16 & +43.36 & 0.42 & 14 \\
\hline $15 \mathrm{POZ}$ & 0.91 & 6 & -5.82 & 0.86 & 6 \\
\hline 16 SZC & 0.39 & 14 & +13.04 & 0.44 & 13 \\
\hline
\end{tabular}

CSIR, cumulative standardised incidence ratio; WCSIR, weighted cumulative standardised incidence ratio. 
itivity by global positivity.

ii) The relative nature of the proposed risk measure provides automatic separation of more risky regions from less risky ones (boundary value=1). If NPIs should be introduced, there is no need of establishing ad-hoc thresholds necessary for local measures (e.g. exceeding 200 new infections per 100,000 inhabitants (Robert Koch Institute, 2021) or exceeding 10\% positivity rate.

iii) Knowledge about dynamical properties of specific risk measures (i.e. why they increase or decrease) along with the analysis of the relationships between different measures is helpful to hypothesise about the epidemiological significance of the observed trends.

iv) In this study, the proposed methodology was investigated for administrative and contiguous regions of Poland. However, it can easily be used for non-contiguous regions or countries provided that the data for the population, infection, and testing are available.

\section{References}

Bai Y, Yao L, Wei T, Tian F, Jin DY, Chen L, Wang M, 2020. Presumed asymptomatic carrier transmission of COVID-19. JAMA - 323:1406-7.

Balcan D, Colizza V, Gonçalves B, Hud H, Ramasco JJ, Vespignani A, 2009. Multiscale mobility networks and the spatial spreading of infectious diseases. Proc Natl Acad Sci U S A 106:21484-9.

Bergquist R, Rinaldi L, 2020. Covid-19: pandemonium in our time. Geospat Health 15:880.

Bertuzzo E, Mari L, Pasetto D, Miccoli S, Casagrandi R, Gatto M, Rinaldo A, 2020. The geography of COVID-19 spread in Italy and implications for the relaxation of confinement measures. Nat Commun 11:4264.

Bivand RS, Pebesma E, Gómez-Rubio V, 2013. Applied spatial data analysis with R. Springer, Berlin, Germany.

Błoński M, 2020a. Kolejne przypadki koronawirusa w kopalniach. Chorzy w Rybniku i Rudzie Śląskiej. Available from: https://biznes.wprost.pl/gospodarka/przemysl/10352303/kolejne-przypadki-koronawirusa-w-kopalniach-chorzy-w-rybnikui-rudzie-slaskiej.html

Błoński M, 2020b. Śląskie: ponad jedna trzecia przebadanych górników z kopalni Bielszowice z koronawirusem. Available from: https://www.pap.pl/aktualnosci/news,689311,slaskieponad-jedna-trzecia-przebadanych-gornikow-z-kopalni-bielszowice-z

Briz-Redón Á, Serrano-Aroca Á, 2020. A spatio-temporal analysis for exploring the effect of temperature on COVID-19 early evolution in Spain. Sci Total Environ 728:138811.

Candido DS, Claro IM, de Jesus JG, Souza WM, Moreira FRR, Dellicour S, Mellan TA, du Plessis L, Pereira RHM, Sales FCS, Manuli ER, Thézé J, Almeida L, Menezes MT, Voloch CM, Fumagalli MJ, Coletti TM, da Silva CAM, Ramundo MS, Amorim MR, Hoeltgebaum HH, Mishra S, Gill MS, Carvalho LM, Buss LF, Prete CA, Ashworth J, Nakaya HI, Peixoto PS, Brady OJ, Nicholls SM, Tanuri A, Rossi ÁD, Braga CKV, Gerber AL, de C Guimarães AP, Gaburo N, Alencar CS, Ferreira ACS, Lima CX, Levi JE, Granato C, Ferreira GM, Francisco RS, Granja F, Garcia MT, Moretti ML, Perroud MW, Castiñeiras TMPP, Lazari CS, Hill SC, de Souza Santos AA, Simeoni CL, Forato J, Sposito AC, Schreiber AZ, Santos
MNN, de Sá CZ, Souza RP, Resende-Moreira LC, Teixeira MM, Hubner J, Leme PAF, Moreira RG, Nogueira ML, Ferguson NM, Costa SF, Proenca-Modena JL, Vasconcelos ATR, Bhatt S, Lemey P, Wu C-H, Rambaut A, Loman NJ, Aguiar RS, Pybus OG, Sabino EC, Faria NR, 2020. Evolution and epidemic spread of SARS-CoV-2 in Brazil. Science (80-.): eabd2161.

Chinazzi M, Davis JT, Ajelli M, Gioannini C, Litvinova M, Merler S, Pastore y Piontti A, Mu K, Rossi L, Sun K, Viboud C, Xiong X, Yu H, Elizabeth Halloran M, Longini IM, Vespignani A, 2020. The effect of travel restrictions on the spread of the 2019 novel coronavirus (COVID-19) outbreak. Science (80-. ):368:395-400.

Chruścińska-Dragan M, 2020. Procesje Bożego Ciała 2020. Czy się odbędą? W tym roku zastąpią je procesje wokół świątyń i przykościelnych placów. Dz. Zach. Available from: https://dziennikzachodni.pl/procesje-bozego-ciala-2020-czy-sie-odbedaw-tym-roku-zastapia-je-procesje-wokol-swiatyn-i-przykoscielnych-placow/ar/c1-14978424.

Cobey S, 2020. Modeling infectious disease dynamics. Science (80-. ) 368:713-4.

Cordes J, Castro MC, 2020. Spatial analysis of COVID-19 clusters and contextual factors in New York City. Spat Spatiotemporal Epidemiol 34:100355.

Dalziel BD, Kissler S, Gog JR, Viboud C, Bjørnstad ON, Metcalf CJE, Grenfell BT, 2018. Urbanization and humidity shape the intensity of influenza epidemics in U.S. cities. Science (80-. ) 362:75-9.

David R, Hayes A, 2019. broom: Convert statistical analysis objects into tidy tibbles. R package version 0.5.2.

Desjardins MR, Hohl A, Delmelle EM, 2020. Rapid surveillance of COVID-19 in the United States using a prospective spacetime scan statistic: detecting and evaluating emerging clusters. Appl Geogr 118:102202.

Franch-Pardo I, Napoletano BM, Rosete-Verges F, Billa L, 2020. Spatial analysis and GIS in the study of COVID-19. A review. Sci Total Environ 739:140033.

Gatto M, Bertuzzo E, Mari L, Miccoli S, Carraro L, Casagrandi R, Rinaldo A, 2020. Spread and dynamics of the COVID-19 epidemic in Italy: Effects of emergency containment measures. Proc Natl Acad Sci U S A 117:10484-91.

Gémes K, Talbäck M, Modig K, Ahlbom A, Berglund A, Feychting M, Matthews AA, 2020. Burden and prevalence of prognostic factors for severe COVID-19 in Sweden. Eur J Epidemiol 35:401-9.

Hatchett RJ, Mecher CE, Lipsitch M, 2007. Public health interventions and epidemic intensity during the 1918 influenza pandemic. Proc Natl Acad Sci U S A 104:7582-7.

Hohl A, Delmelle EM, Desjardins MR, Lan Y, 2020. Daily surveillance of COVID-19 using the prospective space-time scan statistic in the United States. Spat Spatiotemporal Epidemiol 34:100354.

Huang R, Liu M, Ding Y, 2020. Spatial-temporal distribution of COVID-19 in China and its prediction: A data-driven modeling analysis. J Infect Dev Ctries 14:246-53.

Jarynowski A, Wójta-Kempa M, Płatek D, Czopek K, 2020. Attempt to understand public health relevant social dimensions of COVID-19 outbreak in Poland. Soc Regist 4:7-44.

Jia JS, Lu X, Yuan Y, Xu G, Jia J, Christakis NA, 2020. Population flow drives spatio-temporal distribution of COVID-19 in China. Nature 582:389-94. 
Kassambara A, 2020. 'ggpubr': 'ggplot2' Based Publication Ready Plots. R Packag. version 0.2.5.

Krzysztofik R, Kantor-Pietraga I, Spórna T, 2020. Spatial and functional dimensions of the COVID-19 epidemic in Poland. Eurasian Geogr Econ 61:573-86.

Li R, Pei S, Chen B, Song Y, Zhang T, Yang W, Shaman J, 2020. Substantial undocumented infection facilitates the rapid dissemination of novel coronavirus (SARS-CoV-2). Science (80-. ) 368:489-93.

Lieberman-Cribbin W, Tuminello S, Flores RM, Taioli E, 2020. Disparities in COVID-19 testing and positivity in New York City. Am J Prev Med 59:326-32.

Medonet, 2020. Poważny błąd w liczbie testów w Kielcach. Szpital wydał oświadczenie, 2020. Available from: https://www.medonet.pl/koronawirus/koronawirus-wpolsce,koronawirus - kielce-blad-w-raportowaniu-testowoswiadczenie, artykul,68822256.html

Miller IF, Becker AD, Grenfell BT, Metcalf CJE, 2020. Disease and healthcare burden of COVID-19 in the United States. Nat Med 26:1212-7.

Milton Bache S, Wickham H, 2014. Magrittr: a forward-pipe operator for $\mathrm{R}$

Ministry of Health in Poland, 2020. Report on tests. Available from: https://twitter.com/MZ_GOV_PL/status/1292025394 862981122

Ministry of Health in Poland - official Twitter profile [WWW Document], Available from: https://twitter.com $/ \mathrm{mz}$ gov_pl?lang $=\mathrm{pl}$

Mollalo A, Vahedi B, Rivera KM, 2020. GIS-based spatial modeling of COVID-19 incidence rate in the continental United States. Sci Total Environ 728:138884.

Moran PAP, 1950. Notes on continuous stochastic phenomena. Biometrika 37:17-23.

Müller K, Wickham H, 2020. tibble: Simple Data Frames. R package version 3.0.1

Niżankowski R, Myśliwiec M, Szymański P, 2020. Zalecenia w COVID-19. Available from: https://www2.aotm.gov.pl/wpcontent/uploads/covid_19/2020.04.25_zalecenia\%20covid19_ v1.1.pdf

Ogiolda K, 2020. Boże Ciało 2020 w Opolu. Biskupi poprowadzili procesję z katedry 'na górkę.' opole.naszemiasto.pl. Available from: https://dziennikzachodni.pl/procesje-bozego-ciala-2020czy-sie-odbeda-w-tym-roku-zastapia-je-procesje-wokolswiatyn-i-przykoscielnych-placow/ar/c1-14978424

Omori R, Mizumoto K, Chowell G, 2020. Changes in testing rates could mask the novel coronavirus disease (COVID-19) growth rate. Int J Infect Dis 94:116-8.

Orlikowski P, 2020. Nowe ognisko koronawirusa. Przebadano 800 osób, uruchomiono mobilną stację. Available from: https://www.money.pl/gospodarka/nowe-ognisko-koronawirusa-przebadano-800-osob-uruchomiono-mobilna-stacje6539775208421505a.html

Pebesma E, 2018. Simple features for R: Standardized support for spatial vector data. R J 10:439-446.

Pinkas J, Jankowski M, Szumowski L, Lusawa A, Zgliczynski WS, Raciborski F, Wierzba W, Gujski M, 2020. Public health interventions to mitigate early spread of SARS-CoV-2 in Poland. Med Sci Monit 26:e924730-1-e924730-7.

Polish Press Agency, 2020a. Szumowski: rekord zachorowań wynika z badań przesiewowych górników i innych ognisk [WWW Document]. Available from: https://www.pap.pl/aktu-
alnosci/news\%2C659353\%2Cszumowski-rekord-zachorowanwynika-z-badan-przesiewowych-gornikow-i-innych

Polish Press Agency, 2020b. Sasin: od jutra wstrzymamy prace w dwóch kopalniach JSW i w 10 kopalniach PGG [WWW Document]. Available from: https://www.pap.pl/ aktualnosci/ news\%2C658301\%2Csasin-od-jutra-wstrzymamy-prace-wdwoch-kopalniach-jsw-i-w-10-kopalniach

Polsat, 2020. Sasin: Śląsk jest najbezpieczniejszym miejscem w Polsce [WWW Document]. Available from: https://www.polsatnews.pl/wiadomosc/2020-06-19/co-z-wyborami-na-slaskukonferencja-prasowa-szumowskiego-i-sasina/

Polska Grupa Górnicza, 2020. Wygasa epidemia w Polskiej Grupie Górniczej [WWW Document]. Available from: https://www.pgg.pl/aktualnosci/z-zycia-firmy/1110,Wygasa+ epidemia $+\mathrm{w}+$ Polskiej+Grupie+Górniczej

Raciborski F, Pinkas J, Jankowski M, Sierpiński R, Zgliczyński WS, Szumowski Ł, Rakocy K, Wierzba W, Gujski M, 2020. Dynamics of COVID-19 outbreak in Poland: an epidemiological analysis of the first two months of the epidemic. Polish Arch Intern Med 130:615-21.

Ramírez-Aldana R, Gomez-Verjan JC, Bello-Chavolla OY, 2020. Spatial analysis of COVID-19 spread in Iran: Insights into geographical and structural transmission determinants at a province level. PLoS Neglect Trop Dis 14:e0008875.

Ramírez IJ, Lee J, 2020. COVID-19 emergence and social and health determinants in Colorado: A rapid spatial analysis. Int $\mathbf{J}$ Environ Res Public Health 17:3856.

RMF24, 2020. Szumowski: Rozważamy powrót do obostrzeń. Polacy zapomnieli, że mamy epidemię [WWW Document]. Available from: https://www.rmf24.pl/tylko-w-rmf24/poranna-rozmowa/news-szumowski-rozwazamy-powrot-doobostrzen-polacy-zapomnieli-ze,nId,4543089

Robert Koch Institute, 2021. Information on the designation of international risk areas (18 June 2021). Available from: https://www.rki.de/DE/Content/InfAZ/N/Neuartiges Coronav irus/Transport/Archiv_Risikogebiete/Risikogebiete_aktuell_e n.pdf?_blob=publicationFile

Rohleder S, Bozorgmehr K, 2020. Monitoring the spatiotemporal epidemiology of Covid-19 incidence and mortality: a smallarea analysis in Germany. Spatial Spatio-Temp Epidemiol 100433.

Rossman H, Keshet A, Shilo S, Gavrieli A, Bauman T, Cohen O, Shelly E, Balicer R, Geiger B, Dor Y, Segal E, 2020. A framework for identifying regional outbreak and spread of COVID19 from one-minute population-wide surveys. Nat Med 26:634-8

RTL, 2020a. List of countries that have blacklisted Luxembourg. RTL Today. Available from: https://today.rtl.lu/news/luxembourg/a/1547715.html

RTL, 2020b. Germany declares Luxembourg risk region, cautions against non-essential travel. RTL Today. Available from: https://today.rtl.lu/news/luxembourg/a/1549070.html

RTL, 2020c. Germany revises Luxembourg's classification as Covid-19 risk zone. RTL Today. Available from: https://today.rtl.lu/news/luxembourg/a/1567383.html

Runge A, Kantor-Pietraga I, Runge J, Krzysztofik R, Dragan W, 2018. Can depopulation create urban sustainability in postindustrial regions? A case from Poland. Sustain 10:4633.

Sievert C, 2018. plotly for R. Available from: https://plotlybook.cpsievert.me

Statistics Poland, 2020. Demographic yearbook of Poland. 
Available from: https://stat.gov.pl/en/

Statistics Poland, 2020. Local Data Bank. Available from: www.bdl.stat.gov.pl/BDL/start

Tagliazucchi E, Balenzuela P, Travizano M, Mindlin GB, Mininni PD, 2020. Lessons from being challenged by COVID-19. Chaos Solitons Fractals 137:109923.

Tennekes M, 2018. Tmap: thematic maps. R J Stat Softw 84:1-39. TVN24, 2020. Morawiecki: ‘Śmiało idźcie do urn'. A co pokazują dane o pandemii? [WWW Document]. Available from: https://konkret24.tvn24.pl/zdrowie,110/morawiecki-smialoidzcie-do-urn-a-co-pokazuja-dane-o-pandemii,1021761.html

Waller LA, Gotway CA, 2004. Applied spatial statistics for Public Health Data, Vol. 368. ed. John Wiley \& Sons, New York, NY, USA, 520 pp.

Watoła J, 2020. Statystyki koronawirusa coraz bardziej fałszywe. Ministerstwu Zdrowia brakuje na Śląsku już 1,1 tys. przypad- ków. Gaz. Wybor. Available from: https://katowice. wyborcza.pl/katowice/7,35063,26112008,statystyki-koronawirusacoraz-bardziej-falszywe-ministerstwu.html

WHO, 2020. Coronavirus disease (COVID-19) advice for the public [WWW Document]. Available from: https://www.who.int/ emergencies/diseases/novel-coronavirus-2019/advice-forpublic

Wickham H, 2016. ggplot2 Elegant Graphics for Data Analysis (Use R!). Springer, Berlin, Germany.

Wickham H, 2007. Reshaping data with the reshape package. J Stat Softw 21:1-20.

Wickham H, Francois R, Henry L, Kirill M, 2019. dplyr: a grammar of data manipulation. R Packag. version 0.8.3.

Zhang CH, Schwartz GG, 2020. Spatial disparities in coronavirus incidence and mortality in the united states: an ecological analysis as of May. J Rural Health 2020;36:433-45. 